Modern Asian Studies 52, 1 (2018) pp. 214-237. (C) The Author(s) 2018.

This is an Open Access article, distributed under the terms of the Creative

Commons Attribution licence (http://creativecommons.org/licenses/by/4.o/), which permits unrestricted re-use, distribution, and reproduction in any medium, provided the original work is properly cited. doi:10.1017/Soo26749X17000622

\title{
Efficient Donors, Meritorious Receivers: Professionalizing transnational philanthropy in coastal Andhra*
}

\author{
SANAM ROOHI \\ Amsterdam Institute for Social Science Research, University of Amsterdam, \\ Amsterdam, Netherlands \\ National Institute of Advanced Studies, Bangalore, India \\ St Joseph's College, Autonomous, Bangalore, India \\ Emails:sanam.roohi@gmail.com; sanamroohi@sjc.ac.in
}

\begin{abstract}
'High skilled' Kamma migrants from Coastal Andhra domiciled in the USA maintain strong ties with their villages and towns of origin. Since the 199os, one key way in which they have sustained relations with their roots is through transnational philanthropy. Over the last two decades, migrant donors have diversified the modalities of their philanthropic engagements, increasingly institutionalizing them through US-based transnational associations. While the institutionalization of philanthropy may appear to be an import from the USA, closer examination reveals its historical antecedent in the caste-based Varaalu system practised by the Kammas during the late colonial period. The transnationalization of older forms of giving are marked by key modifications in the way giving is conceptualized-from being localized, need based, and individualized to being based on merit, efficiency, and professionalization. The term 'donation' is used to describe their philanthropy, rather than daan or charity, and the politics of semantics points to the modernizing impulse within the community to transcend caste owing to their diasporic location. Yet, by aiming to
\end{abstract}

* This article draws on my $\mathrm{PhD}$ research conducted under the 'Provincial Globalisation Programme', a collaboration between the Amsterdam Institute for Social Science Research (AISSR), University of Amsterdam, the Netherlands, and the National Institute of Advanced Studies (NIAS), Bangalore, India, funded by the WOTRO Science for Global Development programme of the Netherlands Organisation for Scientific Research (NWO). I thank the 'ProGlo' team for all their support during my research. I am grateful to Prof. Filippo Osella and Prof. Sumathi Ramaswamy for their incisive comments in the first draft of this article. I also extend my gratitude to the two anonymous reviewers who gave me sharp and extensive comments for further improving my arguments. Any shortcomings in this article, however, are entirely mine. 
reach deserving beneficiaries while upholding meritocracy, donors often circulate philanthropic resources horizontally on a caste inflected and highly politicized transnational plane. The discourse and practices of transnational giving in post-reform India bring out the contradiction that simultaneously obscures the workings of a caste while transnationalizing its boundaries.

\section{Introduction}

On 4 February 2012, the 1972 batch of Guntur Medical College (GMC) celebrated its Ruby jubilee marking $4^{\mathrm{o}}$ years of existence. About 160 doctors attended the reunion, and some 40 of them were estimated to have travelled across continents-the majority from the USA - to be a part of this event. The celebration took place in the locally famed auditorium built in the early 2000 s with a donation of $5^{\text {o }}$ million rupees ${ }^{1}$ from members of the GMC Alumni Association of North America or GMCANA.

The Ruby reunion was a two-day affair, put together with the generous donations of alumni practising in India and abroad. The event was organized and managed actively through coordination between local and NRI (non-resident Indian) volunteer doctors from the batch. While the first day was a sombre affair, where mementos were distributed and teachers were celebrated for training 'world class' doctors, the second day was celebrated in a more relaxed manner at Hailaand Park ${ }^{2}$ in the outskirts of Guntur. The focus of this day was to brainstorm how participants could be more useful to their alma mater and work together more efficiently to make a better impact of their collective giving. The emphasis was on ascertaining the needs of the college and jointly doing something for the college as a batch. The doctors participating agreed that focused and targeted giving could have better outcomes, and discussed the possibilities of constituting newer scholarships and improving the infrastructure of GMC, amongst other things.

When I started my fieldwork in early September $2011,{ }^{3}$ in Guntur (a regional town in coastal Andhra Pradesh, India), and began asking

\footnotetext{
${ }^{1}$ One rupee or INR is approximately o.o1 USD and 0.014 EUR.

${ }^{2}$ Hailaand Park is a theme park in Chinnakakani, Guntur. It also has a resort.

${ }^{3}$ With Guntur town as my primary research site, I conducted long multi-sited ethnographic fieldwork across different parts of undivided Andhra Pradesh and the USA for 15 months, from September 2011 to December 2012. During this period, I interviewed 208 respondents, followed and participated in the activities of more than
} 
people about NRI engagements in philanthropic projects in the region, Gunturians often suggested that I interview 'NRI doctors' who were the region's pioneers of transnational philanthropy from the early 1990s. They had inspired other NRIs to get involved soon thereafter. I was told that NRIs were doing 'good work for the community', ${ }^{4}$ and having done well for themselves, were now involved in doing 'something for the motherland'. In Guntur, 'NRI culture' is unambiguously equated with a particular caste, the Kammasthe major landowning, agrarian community of Coastal Andhra, which has successfully transitioned into the urban middle classes by pursuing higher education ${ }^{5}$ and entering professional and white-collar occupations. Although many urban middle-class Kammas live outside the region, having migrated across India and abroad, ${ }^{6}$ members of this caste continue to hold important positions of power in the state and the region.

As pioneers of transnational philanthropy, GMC doctors settled in the USA were uniquely placed, given their huge alumni network, to collectively 'give back' to their alma mater and to their region of origin. Altogether, some 1,800 alumni of $\mathrm{GMC}^{7}$ migrated to the USA, most of them between the 1960 s and 1980 s. Many other educated professionals, especially scientists and engineers, also went to the USA from Coastal Andhra, during this period, to pursue higher studies or seek employment. This pattern of migration was reinforced and expanded during the 1990 s due to the 'Y2K boom', when many engineering graduates from the region got jobs in the

a dozen philanthropic projects and took part in ordinary Guntur life, interacting with parents of NRIs who had made Guntur town their home. Out of the 208 respondents, 138 were Kammas and roughly half were parents of NRIs or returned NRIs, and the remainder were NRIs living mostly in the USA. Thirty-five of the NRIs interviewed were women.

${ }^{4}$ During my fieldwork, I often found people co-equating caste with community. In keeping with this practice, I use the word 'community' to refer to the Kammas in this article.

${ }^{5}$ C. Upadhya, 'Social and Cultural Strategies of Class Formation in Coastal Andhra Pradesh', Contributions to Indian Sociology 31 no. 2 (1997), pp. 169-93.

${ }^{6}$ X. Biao, Global 'Body Shopping': An Indian Labor System in the Information Technology Industry (Princeton: Princeton University Press, 2007).

${ }^{7}$ There is no clear evidence on this exodus: 1,800 is an approximate number that was suggested by several reliable sources.

${ }^{8}$ The 'Y2K crisis' refers to the widespread fear that computer systems would become disrupted at the turn of the millennium, on 31 December 1999. To correct anticipated problems, many software engineers were hired, including from India. The 'Y2K' scare turned into a 'Y2K boom' for Indian IT professionals. 
USA and elsewhere in response to the global demand for software engineers. Several of these highly skilled professionals have settled abroad, where they live comfortable upper-middle-class lives and are now eager to 'give back' to their villages or towns of origin, or alma maters, or to support various social development projects in the region.

During the Ruby celebration, many doctors expressed their gratitude to the GMC, highlighting the role of their teachers in training them very well in their various fields of specialization. They also spoke about the benefits of studying in a governmentsubsidized college, where they were charged 'peanuts' or 'next to nothing' for such a 'world-class' professional education. The college further enhanced the 'meritoriousness' of its graduates-a point that was made repeatedly by NRI doctors who presented their ability to migrate to the USA and establish a successful medical practice there as evidence of their inherent 'merit' (augmented by their GMC education). Giving back to the alma mater is thus seen as an act of reciprocity by the alumni. GMC had recognized the merit of the would-be doctors and enhanced it during their MBBS (Bachelor of Medicine, Bachelor of Surgery) course-a point stressed by doctors who presented their migration to the USA and their ensuing practice of medicine there as evidence of this meritoriousness. Their 'wealth and fame' once they became successful was because of their education at the then-famous GMC, and now it was the turn of the alumni to take care of their ailing alma mater, which had lost much of its prestige in the last couple of decades. The alumni felt even more obliged to give to their alma mater to prevent the erosion of their own credentials that are inextricably tied to the status of the medical college.

From the perspective of these NRI doctors, from the GMC's inception in 1948 until the 1990 s largely meritorious students could get a 'seat' (place) in the GMC. However, my interlocutors felt that the college's reputation has spiralled downward because it does not produce the best doctors in Guntur anymore. One reason given for this deterioration of GMC status was that the students entering it were often not meritorious enough, nor were the professors as competent as they used to be. A quick count of the number of intakes by GMC for the years 2013-2014 and 2014-2015 throws into sharp relief their views of 'uplifting' the worsening status of their college. The list shows that a total of 200 students were admitted each year, of whom more than half were from castes 
marked for reservations ${ }^{9}$ and largely seen as undeserving and nonmeritorious. However, roughly 20 per cent of these candidates had acquired a seat through open competition, and not through reserved seat quota. Moreover, the NRI doctors pointed out that the government had also not upgraded the infrastructure of the college. They felt that one way to mitigate the loss in GMC's credibility was through their concerted philanthropic efforts. The alumni abroad were doing what they could to pull up the standards of GMC by investing in equipment and infrastructure and by constituting awards and scholarships to attract the 'best brains' and reward meritocracy.

Over the last two decades, NRI donors have diversified the modalities of their philanthropic engagements, branching out into different areas of intervention and increasingly institutionalizing philanthropy through US-based transnational associations. This marks a shift towards increasing professionalization of transnational philanthropy for more effective and targeted giving, where education becomes a key site of their philanthropic intervention. This article therefore interrogates what accounts for the professionalization of transnational philanthropy in education, and investigates how practices of transnational giving intertwine with the discourse of 'merit' and 'donation' in post-reform India.

Studies on transnational forms of philanthropy (called diaspora philanthropy ${ }^{10}$ ) have only recently started gaining traction, ${ }^{11}$ and are

${ }^{9}$ The constitution of India mandates the reservation of seats in government institutions of higher education and in government jobs for those belonging to the scheduled castes and tribes (SCs and STs) who have historically been the victim of caste oppression and exclusion by upper castes. While seats reserved for SCis and STs were 20 per cent after 1954 , this increased to 49.5 per cent to accommodate other 'backward castes' after Mandal Commission recommendations were implemented during the 1990 .

${ }^{10}$ The term diaspora is marked by rupture or uprooting and when applied to migrant philanthropy also assumes a sense of distance in the process of giving, tempered with rationality and/or ideology. However, my research points to intense processesincluding processes underlying giving-interlocking countries/places of origin and countries of settlement, that is best captured by the concept of transnationalism.

${ }^{11}$ For example see P. F. Geithner, P. Johnson, and L. Chen, Diaspora Philanthropy and Equitable Development in China and India (Cambridge, Massachusetts: Harvard University Press, 2004); B. J. Merz, New Patterns for Mexico in Observations on Remittances, Philanthropic Giving, and Equitable Development (Cambridge, Massachusetts: Harvard University Press, 2005); A. Najam, Portrait of a Giving Community: Philanthropy by the Pakistani-American Diaspora (Cambridge, Massachusetts: Harvard University Press, 2006); P. D. Johnson, Diaspora Philanthropy: Influences, Initiatives, and Issues (Cambridge, 
viewed as a channel of non-elite philanthropy where stakeholders double up as decision makers. ${ }^{12}$ In the Indian context, scholars like Devesh Kapur have highlighted the changing nature of philanthropy, especially its increasing professionalization, ${ }^{13}$ yet from an anthropological perspective this changing nature has hardly been studied.

While the idea of transnational giving may appear to be an import from the USA, owing to the diasporic location and experiences of donors, closer examination reveals its historical antecedent in the changing role of caste and the existing political economy of the region during the late colonial period. With the transnationalization of giving, older forms of giving are now marked by key modifications in the way they are conceptualized-from being localized, need based, individualized and caste inflected, to being based on merit, efficiency, and professionalization. It has been argued that professionally done philanthropy makes altruism more effective, ${ }^{14}$ yet, as this article shows, the discourses and practices of transnational philanthropy in the region that stress efficiency stem from a strong affective domain of being and belonging within a transnational social field ${ }^{15}$ that is inflected by caste. When donors use the term donation, rather than daan or charity to describe their philanthropy, the politics of semantics signify horizontal relationality between the donor and the beneficiary. It also points to modernizing undertones in the usage of this term. The move to increasingly institutionalize giving within transnational associations reflect the donors' attempt to disavow caste in its modern avatar, yet the practices of transnational giving among Kammas exhibit a strong attempt to transnationalize the boundary of a caste, even while obscuring its workings.

Massachusetts: Harvard University Press, 2007); J. M. Brinkerhoff, 'Diaspora Philanthropy: Lessons from a Demographic Analysis of the Coptic Diaspora', Nonprofit and Voluntary Sector Quarterly 43 no. 6 (2014), pp. 969-92.

${ }^{12}$ K. Newland, A. Terrazas, and R. Muster, Diaspora Philanthropy: Private Giving and Public Policy (Washington, DC: Migration Policy Institute, 2010).

${ }^{13}$ D. Kapur, Indian Diasporic Philanthropy: Some Observations (Cambridge, Massachusetts: Harvard University Press, 2007), p. 9.

${ }^{14}$ P. Singer, The Most Good You Can Do: How Effective Altruism is Changing Ideas about Living Ethically (New Haven: Yale University Press, 2015).

${ }^{15}$ P. Levitt and G. N. Schiller, 'Conceptualizing Simultaneity: A Transnational Social Field Perspective on society', International Migration Review 38 no. 3 (2004), pp. 1002-39. 


\section{Professionalization and the changing discourse of giving}

Two transnational associations based in the USA have been at the forefront of transnational philanthropy in Coastal Andhra, and since the 1990 os have pioneered attempts to professionalize diasporic giving. One of them is the GMCANA, as noted earlier. However, prior to the establishment of GMCANA, members of another association-the Telugu Association of North America or TANA, the oldest national Telugu association in the USA — had started a foundation with the aim of providing scholarships to meritorious Telugu students to pursue higher education in the USA. The membership of GMCANA (an alumni body) and TANA (a language-based association in the USA) overlaps substantially. To account for this convergence and explain its significance, I trace the history of these associations, below, and show how they became entangled with one another through diasporic philanthropic activities.

TANA is a cultural organization that started out with the aim of bringing the scattered Telugu population from across the USA together on a common platform once every two years for a grand convention. The number of Telugus in the USA had started to swell in the 1970s, when many well-qualified doctors, engineers, and scientists from Andhra Pradesh started migrating there after the US Immigration and Nationality Act came into effect in $1965 .{ }^{16}$ Though city- or state-based Telugu associations had already existed, a growing need was felt to start a pan-USA Telugu association. TANA came into being with the first convention, organized in 1977. The purpose of the biannual convention was to help the Telugu community remain in touch with their culture and propagate it in a foreign land. The mobile nature of the convention-which was to move from one major US city to another-provided opportunities to as many Telugus as possible to host a convention in their cities of settlement. In 1980, TANA started its foundation. Despite its claim that TANA was for Telugus, the social profile of TANA members exhibited a few strong biases-the members were overwhelmingly from the districts of Guntur and Krishna (many of them alumni of GMC), they were mostly professionals (either doctors, engineers, or scientists), and most were Kamma by caste. The caste character of TANA became a cause of disagreement among

${ }^{16}$ A. Subramanian, 'Indians in North Carolina: Race, Class, and Culture in the Making of Immigrant Identity', Comparative Studies of South Asia, Africa and the Middle East 20, no. 1 (2000), pp. $105^{-14}$. 
non-Kamma members, so much so that soon it came to be known as a 'Kamma Association' and a separate Reddy and Brahmin led faction broke away in 1990, calling itself ATA or American Telugu Association.

GMCANA was founded at the third TANA conference, in 1981 , by GMC alumni members who decided to create a separate body to help alumni touch base with each other, and to foster a professional network of alumni doctors practising in the USA and Canada. In addition, they decided to raise 'money and material to promote teaching and patient care needs at GMG and its affiliated institutions'; ${ }^{17}$ thus GMCANA was born. TANA and GMCANA had an umbilical relationship with several TANA governing body members affiliated to GMCANA. Moreover, for five consecutive alumni meetings thereafter, GMCANA members held their gatherings within the context of the biennial TANA conference. It was only in 1989 that the medical college alumni held a separate meeting for the first time, due to growing anxiety among some members about the TANA-GMCANA overlap. However, the link between TANA and GMCANA continues today, with a GMCANA member becoming the president of TANA (a prestigious position among the Telugu community in the USA) in 2014.

While GMCANA initially focused on health and developing the infrastructure of their alma mater, TANA Foundation's primary focus in its earlier days was providing scholarships to 'needy' and 'meritorious' students to come to the USA and pursue 'any' study of their choice. Thereafter, GMCANA members also started many endowment and scholarship schemes to reward 'toppers' in their areas of specialization, often sending money through TANA Foundation. With a need- and outcome-based approach, GMCANA and TANA leaders raised money among their peers during the biannual conferences, and sometimes in smaller get-togethers preceding the conferences, and sent it to Coastal Andhra for various purposes they perceived would require their financial support. The turning point occurred when GMCANA doctors held their first alumni meeting in Guntur, in 1991, thereby making the engagement even more direct. GMCANA started holding health camps in Andhra Pradesh, often in partnership with TANA and other local hospitals. TANA, too, diversified into other fields, such as rural development. This

${ }^{17} \mathrm{R}$, Tripuraneni, 'We Care: The Story of GMCANA', Third Annual GMCANA Awards Function. 23 December 2002, http://www.gmcana.org/sites/ www.gmcana.org/files/assets/We_Care.pdf, [accessed, 29 December 2017 ]. 
formalization of transnational philanthropy and its diversification in Guntur-Krishna districts through a transnational body was a novel step. Prior to the 1990 , there were very few instances of NRIs giving back for the welfare of the 'Telugu community' 'back home', and whatever examples of NRI engagement existed were on an ad hoc basis. The institutionalization of diaspora philanthropy was in this case built around ideas of 'efficiency' and 'transparency'. According to some of my interlocutors, these forms of giving replicate modern, western philanthropic practices that NRIs have learned from living abroad. For instance, several NRI doctors told me that the practice of donating to their alma mater through an alumni association is an American practice. By living and working in the USA, this group of medical professionals have imbibed a particular 'culture' of giving, which revolves around efficiency and targeted philanthropy.

As further proof of formalization of their giving, complete transparency is maintained from the inception of a project. For instance, philanthropic projects are usually initiated when individual members or a group of members identify an area that requires help and discuss a proposed project with the GMCANA board. If the latter agree, they help to raise funds for the project through the association. While some members donate only money, others take an active interest in monitoring the development and implementation of the project. These health camps or projects usually target particular groups and focus on achieving specific outcomes and outputs-for example, by quantifying the results of health interventions, or identifying a need in the government hospital and pooling resources to bridge it. Details of the funding and progress of projects are made available to all GMCANA members. Thus, the projects undertaken by GMCANA members are organized with transparency, and funded and monitored in an institutionalized and formal manner.

It is worth noting that the period of direct transnational engagement in the region coincided with the period when India liberalized its economy, marking a neoliberal turn towards governance and development policies, ${ }^{18}$ and when Andhra Pradesh became the first state to directly negotiate with the World Bank to restructure its

\footnotetext{
${ }^{18}$ S. Corbridge, and J. Harriss, Reinventing India: Liberalization, Hindu Nationalism and Popular Democracy (Cambridge: Polity, 200o).
} 
economy. ${ }^{19}$ Formalized transnational philanthropy got its biggest boost when the Janmabhoomi Programme took off in Andhra Pradesh in 1997 under the Chief Ministership of Chandrababu Naidu-leader of Telugu Desam Party (also known as a 'Kamma party' as its top leadership is drawn from this group). The programme (in which NRIs became the state's partners in rural infrastructure development) invited citizens including NRIs to listen to the 'call of the motherland' and help in its development. The involvement of the state in harnessing transnational philanthropy is discussed elsewhere. ${ }^{20}$ This formalized or institutionalized mode of transnational philanthropy pioneered by an alumni association and a caste-based cultural association had a cascading effect on Telugu NRIs who imitated GMCANA and TANA Foundation by setting up their own trusts and foundations for philanthropy 'back home'.

With such streamlined modes of engagement, Coastal Andhra NRIs pride themselves in pioneering formalized forms of engagement, unlike their Telugu counterparts from other regions like Telangana. ${ }^{21}$ What unites these various types of NRI led philanthropic engagements in Coastal Andhra is the deployment of a few selected idioms to describe transnational giving-viz. the 'merit' of the donor and the recipient, the 'efficiency' and 'professionalism' with which projects are executed, and the 'worthiness' or 'deservingness' of the receiver weighed in before making her the beneficiary.

'Merit' becomes a key factor when designing the modality of transnational philanthropic engagement in Guntur. Merit has two discernible layers to it: first, it is defined as personal effort through which one succeeds in education and life in general, and second, merit is seen as commensurable to particular caste locations. ${ }^{22}$ Kamma

${ }^{19}$ J. Mooij, 'Hype, Skill and Class: The Politics of Reform in Andhra Pradesh, India'. Commonwealth and Comparative Politics 45 no. 1 (2007), pp. $34-56$.

${ }^{20}$ S. Roohi, 'Transnational Citizens as Partners in Development: The case of NRI Cell in Guntur, Coastal Andhra'. In Provincial Globalisation Regional Diasporas and Transnational Flows to India, ed. C. Upadhya, M. Rutten and L. Koskimaki (London: Routledge, 2018).

${ }^{21}$ During the time of my fieldwork, Telangana NRIs have also been involved in various projects in their places of origin but these were later developments, barring a couple of examples, they were not usually organized or institutionalized in a systematic way. There are indications of change after the bifurcation of Andhra Pradesh into Telangana and the truncated state of Andhra Pradesh in 2014.

${ }^{22}$ A similar argument has been made by A. Subramanian, 'Making Merit: The Indian Institutes of Technology and the Social Life of Caste', Comparative Studies in Society and History 57, no. 2 (2015), pp. 291-322. 
doctors and engineers from Guntur-Krishna districts who form the donor base, strongly identify themselves as being hard working and meritorious when compared to other castes (including those who are equal to them or below them in hierarchy). These donors are inclined to promote merit through their philanthropic engagements. Formalizing philanthropy helps them to reach out to deserving beneficiaries who are considered meritorious and needy, but who do not hail from 'reserved categories'. For instance, TANA scholarship endowments to help 'needy' and 'meritorious' students to pursue higher education in India and in the USA are not unencumbered and are free to go to the unmarked 'deserving' candidate. The official statement of the association makes it clear who the intended recipients are:

Meritorious students are selected from low-income families that make less than Rs 65, ooo per year and do not belong to any reservation category and as such do not receive any financial support from the Government. According to the current policy in Andhra Pradesh the Government reimburses tuition fee for professional studies for these students. However there are many left behind without any support. ${ }^{23}$

TANA and GMCANA are not the only associations that have instituted schemes based on merit that exclude recipients from 'reserved categories', thereby excluding lower caste candidates. This exclusion was often the norm for other transnationally funded scholarship schemes in the region. Moreover, such exclusions point to a shift in the political economy of caste where expressions of caste are often equated with 'dirty politics', backwardness, and reaping benefits from governmental schemes without expending labour. In a postMandal and post-liberalization India, those who belong to 'reserved categories' are also those relegated at the bottom rung of a caste schema. In contrast, those belonging to unreserved categories are often seen as a collective that have overcome caste by virtue of not being able to leverage it for government concessions in publicly funded education and government jobs, and therefore relying on their merit and hard work for these. Institutionalized transnational giving, and its recasting via discourses of merit and donation, should be seen as an outcome of the changing political economy of caste in India and in Andhra Pradesh. The desire on the part of well qualified

${ }^{23}$ TANA, 'Scholarships in Andhra Pradesh', in TANA Foundation, 2017, http://www.tana.org/foundation/scholarships/scholarships-in-india, [accessed 29 December 2017]. 
Kamma donors to style themselves as modern philanthropists who have transcended caste is at odds with the way their transnational philanthropic engagements actually unfold on the ground, where the targeting of beneficiaries is circumscribed by caste, as I illustrate below. For donors, their beneficiaries must not only be needy, as needbased giving is an act of charity or daan, they must also be meritorious, to allow for a more professional approach to philanthropy to foster. The collapse of need with merit when identifying beneficiaries demarcates receivers into those worthy and unworthy, where the worthy are already marked by caste by virtue of not being from the 'reserved category' and therefore clearly being from one of the forward castes. ${ }^{24}$ This form of giving is not new, however, and its history can be traced to the Varaalu system practised in Coastal Andhra among the Kammas during the first half of the twentieth century.

\section{From Varaalu to Kakatiya ${ }^{25}$ Society}

What NRIs do is not daan, daan is for the poor, daan is for temples. Nageswar Rao, 68, businessman ${ }^{26}$

Literature on daan (the Indian term for giving) suggests that the desired goal of daan is that it should be non-reciprocated ${ }^{27}$ and disinterested, ${ }^{28}$ paralleling the idea of Derrida's 'true gift' where the donor and receiver forget about the gift immediately. ${ }^{29}$ Moreover, in

${ }^{24}$ Castes that are not covered by reservations are considered 'forward caste' and officially referred to as 'general category'.

${ }^{25}$ Kakatiyas were a dynasty ruling parts of present day Telangana between early 1100 to 1300 . Kammas often use the term Kakatiya for their various caste based organizations as some suggest Kakatiyas were Kammas, while others suggest that they were ministers under Kakatiyas and started flourishing as a community from then on.

${ }^{26}$ Nageswar Rao is one of my 'key informants' with whom I was last in touch in April 2015. This particular conversation I had with him took place in December 2014 in a temple of which he is a trustee. The temple is locally known as the 'Kamma temple' because it was built with money from local and NRI Kammas and managed by Kammas, many of whom are 'NRI Parents'.

${ }^{27}$ J. Parry, 'The Gift, the Indian Gift and the "Indian gift", Man n.s. 21, no. 3 (1986), pp. 453-73.

${ }^{28}$ J. Laidlaw, Riches and Renunciation: Religion, Economy, and Society among the Jains (Oxford: Clarendon Press, 1995); M. Heim. Theories of the gift in South Asia: Hindu, Buddhist, and Jain Reflections on Dana (London: Routledge, 2004).

${ }^{29}$ J. Derrida, Given time: I. Counterfeit Money (Chicago: University of Chicago Press, 1992). 
practice daan has been characterized by asymmetry between givers and receivers, where qualities of the giver flow to the receiver. ${ }^{30}$ However, recent scholarship on daan shows that it has acquired newer attributes reflecting the way giving is changing in India. Daan, which is fleeting and often impulsive, is increasingly seen in a rational-instrumental way. ${ }^{31}$ Daan in contemporary India relies heavily on invoking the worthiness of the receiver (a non-traditional concept)—a strategy that builds accountability into the modernist philanthropic forms of daan. ${ }^{32}$ While the meaning of daan may have changed over the years, this literature continues to see daan as a key term that defines 'Indian' giving. Yet, closer inspection reveals that the term daan may not be translatable to the different forms of giving that make up this moral universe of 'Indian' giving. In Coastal Andhra, what underpins transnational giving is not what traditional literature on Indian giving or daan suggests - it is neither asymmetrical nor non-reciprocal. As the extract above implies, the meaning of daan for the Kamma Telugus I interacted with did not translate into philanthropy. Daan is what one gives to the mendicant or to temples for feeding these mendicants. NRI philanthropy, on the other hand, is expressed through the term donation, which is both reciprocal and symmetrical as I show through the following case.

Dr Jasti Koteswar Rao, GMC alumni, was in his early eighties when I interviewed him in February 2012. He migrated to the USA in the early 1970 , lived and practised in the Midwest (like many Telugu doctors of his generation) for more than three decades, and finally returned to Guntur in 2000 to dedicate his 'life and expertise to the people of Guntur'. Dr Rao recounted how, from being a 'poor village boy', he became a 'successful doctor in Michigan' because of community help. Behind his professional 'success' was not only his own 'hard-working' nature, but a story of gracious community members who provided financial help and took over the responsibility for his education when he was young. Had it not been for the community, he would not be where he is, he averred. He was helped as a student

\footnotetext{
${ }^{30}$ For discussions of the flow of inauspiciousness from the giver to the receiver see J. Parry and M. Bloch, Money and the Morality of Exchange (Cambridge: Cambridge University Press, 1989); G. G. Raheja, The Poison in the Gift: Ritual, Presentation, and the Dominant Caste in a North Indian Village (Chicago: University of Chicago Press, 1988).

${ }^{31}$ E. Bornstein, 'The Impulse of Philanthropy', Cultural Anthropology 24 no. 4 (2009), pp. 622-51.

${ }^{32}$ J. Copeman, 'The Gift and its Forms of Life in Contemporary India', Modern Asian Studies $45^{\text {no. }} 5$ (2011), pp. $105^{1-94}$.
} 
by a rich man who took care of his educational needs under what was known as the Varaalu system, which ultimately helped him get a seat in the 'prestigious' Guntur Medical College. Once in the college, he was provided with free lodging and food at the Kamma Boys Hostel in Guntur. His success story is tied to this community help he received as a student, and now with retirement and surplus time and money in hand he decided to dedicate himself to help the 'poor and meritorious students' of his community by starting the Kakatiya Society-a scholarship disbursing body, the details of which I return to later in the article.

The now defunct (and as I argue mutated into newer forms of giving) Varaalu system was prevalent in Coastal Andhra in the early twentieth century. In this system, richer caste members residing in towns that had schools and colleges would provide food and shelter to underprivileged Kamma students from nearby villages, who would come to study there. Students would often take help from two or more families, and stay with them on a weekly (vaaram in Telugu) rotational basis. Instances of Varaalu existed even during the $1960 \mathrm{~s}$ and 1970s, after which it tapered off, coinciding with the advent of Green Revolution technologies in Guntur-Krishna and Godavari districts $^{33}$ that increased the prosperity of the region.

Varaalu is not a well-documented practice, but it does find a mention in Ramesh Bairy's work (2009) ${ }^{34}$ as Varanna, wherein poor Brahmin male students in the erstwhile Mysore state were provided food by urban-dwelling Brahmins on a weekly basis. Both Varanna and Varaalu were caste-inflected urban practices wherein richer caste members took care of the food (in case of Guntur, even lodging and other needs) of students who came to study in cities. While students may have undergone humiliation, that was to be seen as an aberration, because Varaalu was a claim that poorer hard-working students could make on their own richer urban dwelling caste fellows who were obliged to give support to these students and facilitate the noble cause of acquiring higher education by their wards.

According to popular local narratives, the Kammas-hitherto excluded from the benefits of education-did not initiate Varaalu, but

\footnotetext{
${ }^{33}$ For detailed discussion on the impact of the Green Revolution in the region, see C. Upadhya, 'The Farmer-Capitalists of Coastal Andhra Pradesh', Economic and Political Weekly 23 no. 28 (1988), pp. 1376-82.

${ }^{34}$ R. Bairy, Being Brahmin, Being Modern: Exploring the Lives of Caste Today (New Delhi: Routledge, 2013).
} 
adopted it from the Brahmins of the region to achieve educational, and by extension, social parity with them. Locals also narrate how institutes of quality higher education were in place because of missionary activities, particularly in Guntur district, ${ }^{35}$ and the region also built private schools in pre-independent times by collecting donations from richer caste members. ${ }^{36}$ The emulation by Kammas of Brahminical practices to achieve social mobility is similar to the case of Izhavas whose upward mobility strategies were to adopt Nair referent practices. ${ }^{37}$ However, choosing education as a strategy of community-led efforts to uplift members of ones caste is not universally found across the Indian sub-continent. Some regional groups showed a proclivity for this, as shown by the examples of the Brahmins of Mysore and Tamil Nadu, ${ }^{38}$ or as demonstrated by the Kammas of Coastal Andhra. Other regional groups exhibit different strategies of community-led efforts to attain or maintain socially mobile status: either adopting consumption practices of those higher up in the hierarchy, ${ }^{39}$ or playing larger political roles in their regions of dominance to arrest downward mobility, ${ }^{40}$ or even regulating a traditional low caste occupation and converting it into a skilful trade within the diasporic group. ${ }^{41}$

The Varaalu system coincided with the Non-Brahmin Movement that had engulfed the Madras Presidency region. Scholars may not agree on whether the movement catered to the powerful non-Brahmin upper

${ }^{35}$ R. E. Frykenberg, Christianity in India (New York: Oxford University Press, 2008).

${ }^{36} \mathrm{~S}$. Ananth, The Culture of Business: A Study of the Finance Business in the Vijayawada Region of Andhra Pradesh (PhD dissertation, University of Hyderabad, 2007), pp. 102 and K. B. Chowdary, A Brief History of the Kammas (Guntur: Sangam Jagarlamudi, 1954).

${ }^{37}$ F. Osella, F. and C. Osella, 'Articulation of Physical and Social Bodies in Kerala', Contributions to Indian Sociology 3o no. 1 (1996), pp. 37-68 and F. Osella and C. Osella, Social mobility in Kerala: Modernity and Identity in Conflict (London: Pluto Press, 200o).

${ }^{38}$ For examples of South Indian Brahmins see R. Bairy, 'Brahmins in the Modern World: Association as Renunciation'. Contributions to Indian Sociology 43 no. 1 (2009), pp. 89-1 20; C. J. Fuller, and H. Narasimhan, Tamil Brahmans: The Making of a MiddleClass Caste (New Delhi: Social Science Press, 2014).

${ }^{39}$ Osella and Osella, Social Mobility in Kerala.

${ }^{40}$ C. Jeffrey and J. Lerche, 'Stating the Difference: State, Discourse and Class Reproduction in Uttar Pradesh, India', Development and Change 31 no. 4 (2000), pp. $857-78$.

${ }^{41}$ U. Dhupelia-Mesthrie, 201 2. 'Gujarati Shoemakers in Twentieth-century Cape Town: Family, Gender, Caste and Community', Journal of Southern African Studies 38 no. 1 (2012), pp. 167-82. 
castes $^{42}$ or the self-respect of the lower castes,${ }^{43}$ but they agree that the dislodging of the figure of the Brahmin from positions of pre-eminence was the goal. Ramaswamy ${ }^{44}$ details this colonial movement that spread through much of the Madras Presidency, including Guntur-Krishna delta region, which was undergoing a transformation under the British that caused dominant groups like the Kammas to ascend in economic and political power in this region during the late colonial period. ${ }^{45}$

This was also the period of social and political churning, marked by the emergence of caste associations across Andhra ${ }^{46}$ and the rest of British India, either to jointly demand for greater bargaining power from the British, ${ }^{47}$ or for upgrading in ritual status, especially during the administration of the caste census, ${ }^{48}$ or even to work towards bringing internal reforms in caste-based practices. ${ }^{49}$ Caste associations can be seen as a way through which colonial sovereignty hedged its bets across India, ${ }^{50}$ giving leveraging power to communities, vis-à-vis one other. Unsurprisingly, therefore, caste associations also arose within the early Indian diaspora. For instance, caste associations emerged in Mauritius and worked to create corporatized community identity among Indians who used it to bargain with the local government, thereby performing the role of a political interest group'. ${ }^{51}$ A similar finding was also observed among the Gujarati

${ }^{42}$ P. Price, 'Ideology and Ethnicity under British Imperial Rule: "Brahmans", Lawyers and Kin-Caste Rules in Madras Presidency'. Modern Asian Studies 23 no. 1 (1989), pp. $15^{1-77}$.

${ }_{43}$ M. S. S. Pandian, Brahmin and Non-Brahmin: Genealogies of the Tamil Political Present (Delhi: Permanent Black, Delhi, 2007).

${ }^{44}$ U. Ramaswamy, 'The Belief System of the Non-Brahmin Movement in India: The Andhra Case', Asian Survey 18 no. 3 (1978), pp. 290-300.

${ }^{45}$ C. Baker and D. A. Washbrook, South India: Political Institutions and Political Change, I880-I940 (Delhi: Macmillan Company of India, 1975).

${ }^{46}$ Ramaswamy, 'The Belief System of the Non-Brahmin Movement'.

${ }^{47}$ For a detailed analysis of the role of caste associations in different parts of British India, see F. F. Conlon, 'Caste by Association: The Gauda Sarasvata Brahmana Unification Movement'. Journal of Asian Studies 33 no. 3 (1974), pp. 351-65; S. Bandyopadhyay, Caste, Culture and Hegemony: Social Dominance in Colonial Bengal (Delhi: Sage, 2004).

${ }^{48}$ Bairy, Being Brahmin, Being Modern.

${ }^{49}$ R. Jeffrey, 'The Social Origins of a Caste Association, 1875-1905: The Founding of the SNDP Yogam', Journal of South Asian Studies 4 (1974), pp. 39-59; C. J. Fuller, The Nayars Today (Cambridge: Cambridge University Press, 1976).

${ }^{50}$ R. Birla, Stages of Capital: Law, Culture, and Market Governance in Late Colonial India (Durham: Duke University Press, 2009), p. 237.

${ }^{51}$ See O. Hollup, 'The Disintegration of Caste and Changing Concepts of Indian Ethnic Identity in Mauritius', Ethnology 3 no. 4 (1994), pp. 297-316, here p. 308. 
Mochis (cobbler), a caste given lower position in the hierarchy, who achieved upward mobility as a community in Africa by regulating their trade and projecting it as an occupational specialization rather than as a caste identity, and their caste associations survived until much later. ${ }^{52}$ A corresponding change in ritual status was also found among the dominant Patel caste of Gujarat. Though not so drastic a change, scholars point out how, through migration and remigration, Patidars who were lower-caste Kanbis achieved a higher ritual status. ${ }^{53}$

As elsewhere, in parts of Andhra, community leaders made a case for enhancing community status by building caste associations as a platform where some of their ideas and plans could be executed. Ramaswamy $^{54}$ informs us that almost every caste that was active in the Non-Brahmin movement had built a caste association. For example, the Kamma Mahajana Sangam was founded in 1914 under the guidance of the Raja of Chellapalli and other prominent Kammas. The Reddy Mahajana Sangam was started in 1920 with an official journal entitled Reddy Rani. The Velamas, too, founded an association around this time. ${ }^{55}$ Caste associations worked to unite sub-jatis, ${ }^{56}$ achieve upward mobility in the caste hierarchy, and wrest concessions from the British in pre-independent India. These caste associations obligated giving by the community notables through the associations, for not only the weaker sections of their community, but for the dynamically defined 'interests' of the community, which changed over time. Therefore, caste associations in Coastal Andhra did not always function the same way throughout their history, and their importance plummeted after independence in the $195^{\circ}$ os and 1960s. Carrying out research in the 1960 s, Elliot observed:

By comparison with caste associations elsewhere, those in Andhra have been less self conscious in their conception. Their histories show an increasing embarrassment over identification with caste. The establishment of one Kammas hostel in Krishna brought much controversy over the use of Kamma in the hostel name, for the leaders were anxious to demonstrate that all caste

${ }^{52}$ Dhupelia-Mesthrie, 'Gujarati Shoemakers'.

${ }^{53}$ V. P. Chandra, 'Remigration: Return of the Prodigals-An Analysis of the Impact of the Cycles of Migration and Remigration on Caste Mobility', The International Migration Review 31 no. 1 (1997), pp. 162-7o.

${ }^{54}$ Ramaswamy, 'The Belief System of the Non-Brahmin Movement'.

${ }^{55}$ Ibid., p. 294 .

${ }^{56}$ In India, caste affiliations are based on jatis or endogamous, self-governing, occupational communities or groups that are often regionally defined. Each jati is further subdivided into sub-jatis. Sub-jatis have shown greater tendencies of merging under the overarching main jati in post-colonial India. 
[sic] could use the facility. They eventually used the name in order to appeal to traditional landlords for funds, but did not restrict the membership. ${ }^{57}$

However, by the end of the 1970 , there was a revival of caste associations and their identification with projects of caste consolidation. A host of Kamma caste associations sprang up in the late 1970 in different parts of Andhra Pradesh, according to Apparao, ${ }^{58}$ one of the founders of the Kamma caste association in Guntur. ${ }^{59}$ This point was corroborated by the members of a famous Kamma caste association in Hyderabad that was formed around the same time. The revival of caste associations in the late 1970 occurred at a time when earlier community practices of Varaalu were waning and outward migration had started to take root in the region. These caste associations across different parts of Andhra Pradesh felt the community was 'breaking up', in Apparao's words, and they wanted the new caste associations to take up the work carried out by community notables of pre-independent period. With transnational migration and a sense of disintegration of community and cultural values among migrants in the USA, I argue that it is organizations like TANA and Kakatiya Society that take up the project of building community cohesiveness transnationally.

Dr Jasti Koteswar Rao, who started the Kakatiya Society, had received community help during the 1950s and 196os. As mentioned earlier, he was a varaalu abbai (abbai means boy in Telugu) during his secondary education and then stayed at the Kamma Boys Hostel in Guntur when he was doing his MBBS in GMC, thereafter migrating to the USA as a successful NRI doctor. Through 'hard work' he gained a reputation for himself among community members in Guntur and in the USA, and when he returned to Guntur after retirement, he utilized the opportunity to ask for donations from them to raise funds for Kakatiya Society, to fund the education of deserving Kamma schoolgoing students. It was a reciprocal gesture to help the community that helped him become a successful doctor in the USA. Upon his return to India in 200o, Dr Rao made Guntur town his home, and with the help of some caste notables in Guntur and in the USA, he registered Kakatiya Society in the USA in 2004. Many NRIs there had money and

\footnotetext{
${ }^{57}$ C. M. Elliot, 'Caste and Faction Among the Dominant Castes: The Reddies and Kammas of Andhra', in Caste in Indian Politics, ed. R. Kothari (New Delhi: Orient Longman, 1970, pp. 129-71.

${ }^{58}$ No real names of individuals are used to maintain anonymity.

${ }^{59}$ I interviewed Apparao on 12 January 2012.
} 
the 'heart' to donate, he explained. It was an initiative to help school students from poor Kamma families in Guntur by providing them with scholarships. I paraphrase an official entry ${ }^{60}$ about the Society that describes its mandate, but omits mentioning that the scholarships are only meant for Kamma students with very rare exceptions:

The Kakatiya Society was established in the year 2004 by philanthropically oriented people settled in Canada, America and India. The main aim of the Society is to help financially the poor, deserving students with academic merit who are pursuing post-graduation in technical education, medical education or other professional courses. The Society invites applications from all over Andhra Pradesh in the month of November and those selected will receive financial aid by way of cheques before the end of February every year.

As of 2012, altogether there were 66 donors listed, of which 47 are residents of the US and 17 are local Gunturians. These donors are keen to give financial aid to 'brilliant' school-going students, or students who are rank holders in their class, but have difficulties paying school fees. A part of the scholarship is also given to exceptional students who seek higher education but do not have the means to pay for it. However, not all degrees are treated as equal; there is a hierarchy of different fields of study, where only medical, technical, or scientific education, or promising jobs like pharmacy, are given primacy.

Coinciding with my fieldwork, I had the opportunity to take part in the scholarship distribution function held in January 201 2. December and January are relatively cooler months in Coastal Andhra, and this is a favoured time for NRIs to make a visit back to their Swanthaooru. ${ }^{61}$ Since most donors for the scholarship programme live in the USA, often one or more of the big donors plan their visit to India to coincide with the scholarship distribution ceremony. That year, two prominent NRI donors and two returned NRI donors attended the ceremony. Others who were present during the ceremony included local donors (though NRI donors outnumber local donors, since they stay in Guntur, locals were present in larger numbers at the function) who had also made endowments to the Society. Most of these local donors are also 'NRI Parents' or parents of NRIs. Around 100 scholarships were distributed to school students of different classes that day. Every award was funded by endowments given by particular donors, and when the

${ }^{60}$ I paraphrase the entry, without providing the link to the website, to maintain the anonymity of Dr Rao.

${ }^{61}$ Swanthaooru means one's village in Telugu, and also stands for one's place of origin. 
awards were distributed, the names of the recipient as well as the donor were called out to a round of applause. All donors were Kammas and so were the recipients. ${ }^{62}$

The Kakatiya Society was started with the idea of drawing donations or funds from affluent community members working and living in the USA, to be distributed to meritorious and needy Kamma students. In its initial days it raised money from NRIs and channelled the awareness and fund collection drive through TANA. The total money raised that year was 'INR 700,000 and US\$28,000', as the annual yearbook informs us. Only half a million rupees was spent in the first round of scholarship distribution and the rest of the money was kept in a bank as seed capital, managed by the Trust that ran the Society. Between 2004 and 201 2, the Kakatiya Society has distributed scholarships worth 25 million rupees and it has a corpus of another 20 million rupees, the interest of which supports Kamma students' scholarships. Though the initial corpus was raised from only NRI Kammas through TANA, later the local Trust managing the Society exhorted rich Kammas in Guntur to come forward and give money for the 'needy children of the community'. In Guntur, caste notables are obliged to donate when asked to contribute for philanthropic projects run by their community members, and when asked, many stepped forward to donate money for Kakatiya Society.

As this detailed example of Kakatiya Society illustrates, donation becomes a practice through which wealthier caste members dispense patronage to less privileged people within their own caste. The performance of philanthropy enhances their own and their families' social standing within the community. Community charity is not limited only to Coastal Andhra Kammas. Wealthy Kammas and Telugus living in other parts of Andhra Pradesh, such as Rayalaseema, ${ }^{63}$ also contribute to welfare initiatives for less affluent

${ }^{62}$ While talking to the president of the Kakatiya Society, I learnt that in some rare instances, a few scholarships could be given to deserving students of other caste (he could cite example of a Muslim and a Kapu student), but confirmed that the scholarships are meant for Kammas largely.

${ }^{63}$ In the popular imagination, Rayalaseema is a 'backward' and violence-prone region of Andhra Pradesh. The Reddys are dominant in the region in terms of landholding. See N. Kumar, Egoism, Anomie and Masculinity: Suicide in Rural South India (Andhra Pradesh) (PhD dissertation, London School of Economics, London, 2011 ). In 2014, Andhra Pradesh was bifurcated into the two states of Telangana and (residual) Andhra Pradesh (that included Rayalaseema) following a long political struggle for a separate Telangana state. Parts of Rayalaseema were under Hyderabad State, whereas the Coastal Andhra Kammas were under the Madras Presidency, and the 
community members. But the difference is that, while only a handful of rich Rayalseema Kammas become donors, in Coastal Andhra, owing to the expanding number of NRI households, community welfare activities are more broadly based and are pursued by affluent middleclass members. When I inquired with the Rayalaseema Kammas about the relative lack of philanthropy among them, they attributed it to the lack of money, education, and Western migration from the region. This in turn had created very few Kamma patrons or donors in that region; most of these were businessmen, unlike their educated professional Coastal Andhra counterparts.

In towns like Guntur in Coastal Andhra, every Kamma household having a well settled NRI engages in some form of philanthropy, thereby incorporating transnational giving into their habitus. ${ }^{64}$ This habitus is shaped as much by the place from which migrants come as by their caste. With the expanding scope of giving, Coastal Andhra NRIs and their families have recursively cultivated the image of themselves as a 'community that gives'. In their modernist discourse, caste is replaced by place and many of my Kamma NRI interlocutors identified themselves as part of the 'Telugu community' or as Andhraites from Coastal Andhra (as opposed to Telugus from the Telangana or Rayalaseema regions-the three regions that made up Andhra Pradesh prior to 2014), who were inclined to 'give back'.

\section{Efficiency, meritocracy, and caste politics}

Kakatiya Society and TANA encapsulate the changing face of caste association. Though not one in a traditional sense, the Kakatiya Society was performing the functions of caste associations in the late colonial era-becoming a platform, albeit a transnational one, where community needs (particularly the education of youth) are taken care of through donations by caste notables. Moreover, the Society works closely with the Kamma Sangham (Kamma caste association) in Guntur. What has changed is that now the inflow of resources is through the munificence of transnational donors. Traditionally, caste notables lived in the towns where caste associations had their office or presence. But with increasing transnationalization of Kammas

now-partitioned Andhra Pradesh reflects the unsuccessful attempt to unite Teluguspeakers from British India with those from the erstwhile Hyderabad State.

${ }^{64}$ P. Bourdieu, The Logic of Practice (Stanford: Stanford University Press. 1992). 
in towns like Guntur, the figure of the caste notable has also undergone change. No longer is he the traditional big man, ${ }^{65}$ but a reformed, modernized, socially and spatially mobile, and highly educated member of the transnational community. The education he has (for often the space of community giving is a masculine one with just a little room for women) is indicative of his worth (an MBBS degree is placed at the top, having the most value in the hierarchy of degrees, followed by a software engineering degree) along with his NRI status. If he is a big player in the politics of TANA, the worth of the NRI increases in the eyes of the local and transnational Kammas, and with it grows his responsibility towards the community.

When a student approaches such a donor for accommodation in a hostel, a scholarship, or a school or college seat, she has to first prove her merit either through tests or past performances. Yet, as my study shows, this is not the only way in which admissions are sought, and students often use back door channels and political networks to get a 'merit based' scholarship, accommodation, or a seat; however, this aspect is side-lined when the narrative of merit becomes selfreinforcing.

TANA, as an association of professionals, along with GMCANA as an alumni association of doctors, streamlined and formalized philanthropy in Guntur, executing projects professionally and efficiently. Sometimes my interlocutors would describe their causedriven philanthropy as an import from the USA. This invocation of the American way of doing philanthropy was meant to reflect their own modern urbanized selves. It was an attempt to delink them from local ways of doing religious charity in temples or giving in an unorganized way. While community-led giving for purposive goals has an older history in the region, and Varaalu was one of its expressions, the transnationalization of older forms of giving marked a shift in the way giving is conceptualized. Under Varaalu, giving was localized, need-based, and individualized, and only a handful of caste notables were the donor-patrons. Today, transnational philanthropy is based on merit, efficiency, and professionalization. The term 'donation' is used to describe their philanthropy, rather than daan or charity, and

${ }^{65}$ M. Mines and V. Gourishankar, 'Leadership and Individuality in South Asia: The Case of the South Indian Big-Man', The Journal of Asian Studies 49 no. 4 (1990), pp. 761-86; A. Piliavsky, 'Introduction', in Patronage as Politics in South Asia, ed. A. Piliavsky (Cambridge: Cambridge University Press, 2014), pp. 1-35; F. Osella, 'The (Im)morality of Mediation and Patronage in South India and the Gulf', in Patronage as Politics in South Asia, pp. 367-95. 
the politics of semantics points to the modernizing impulse within the community to transcend caste owing to their diasporic location. Yet, by aiming to reach deserving beneficiaries while upholding meritocracy, donors often circulate philanthropic resources horizontally on a caste inflected and highly politicized transnational plane.

The moment Coastal Andhra Kamma NRIs chose to engage with their region overlaps with the ascendance of the Telugu Desam Party (TDP) in Andhra Pradesh. Such engagements peaked during Chandra Babu Naidu's Chief Ministership between 1995 and 2004, where Kammas believe merit won over red-tape, after TDP won over the 'corrupt' Congress party. Naidu who returned to power in 2014, is acclaimed as a technocrat, embodying Kamma spirit of hard work and merit, who opened the gates for education and further migration ${ }^{66}$ during his earlier stint as the Chief Minister. He is said to have made education accessible to 'all' by privatizing it ${ }^{67}$-but, paradoxically, he paved the way for students with money (mostly from the dominant castes) to acquire expensive technical degrees with ease in private colleges. In Coastal Andhra, these private colleges, often owned by Kammas, have a reputation of being run more professionally than the government ones. ${ }^{68}$ Merit, therefore, already exists in caste-marked Kamma bodies, but migration to the West, particularly the USA, enhances their already existing merit, which is then reflected in the professional way they engage in philanthropic projects.

\section{Conclusion}

Successful American NRI professionals belonging to land-owning agrarian Kamma castes started engaging in organized philanthropy in Coastal Andhra since the mid-199os. This article shows that with

\footnotetext{
${ }^{66}$ Migration following the IT boom is largely credited to be Chandra Babu Naidu's handiwork because of his emphasis on IT education and training.

${ }^{67}$ S. Kamat, 'The Privatization of Public Interest: Theorizing NGO Discourse in a Neoliberal Era', Review of International Political Economy 11 no. 1 (2004), pp. 155-76.

${ }^{68}$ During my fieldwork period the government was under the Reddy-led Congress party which became a continuous target of allegations of corruption. Seen in this light, the 'meritorious' becomes not only the other of the 'reserved category' groups, but also a foil to the other corrupt forward castes. The rivalry between Kammas and Reddys and its shaping of local Andhra as well as American Telugu politics has been discussed in detail in my thesis, see S. Roohi, Giving Back: Diaspora Philanthropy and the Transnationalisation of Caste in Guntur (India) (Unpublished dissertation submitted to University of Amsterdam, 2016).
} 
intense migration out of the region, philanthropy becomes a peg around which a dispersed caste-based community begins to cohere. Put in other words, transnational philanthropy or giving is one of the crucial means through which intra-community relations are forged on a transnational plane that links Coastal Andhra to the USA. Kamma migrants from Coastal Andhra see philanthropy as a means through which a meaningful relationship with the 'home' can be established, particularly in times when the state supposedly excludes them from its welfarist agenda.

Having professionalized their giving through transnational associations, they target 'deserving' beneficiaries for these projects. By following the politics of who gets included in the category of the deserving and who gets excluded, I argue that professionalization of transnational philanthropy simultaneously mask caste identities through practices of giving at one level, and reinscribe it at another level within a transnational field of operation. The language of 'merit' and 'need' also brings to the fore the discomfort of expressing caste affiliation, which gets replaced by more acceptable ways of belonging-by identifying with place-based affiliation. Kammas identify themselves as belonging to Coastal Andhra and the USA. Yet, caste is still at work when potential beneficiaries are identified negatively (by excluding certain categories from becoming beneficiaries as is the case for TANA and GMCANA scholarship programmes) or positively (as in Kakatiya Society's scholarship schemes meant exclusively for Kammas).

The practice of professionalized giving and the discourse of merit indexes a tension between the desire on the part of donors to style themselves as modern philanthropists who have transcended caste, and the continued channelling of philanthropy through caste and caste-based networks. This unease with a more explicit articulation of caste affiliation as the basis for philanthropy is likely heightened by their location in the USA where the imperative to disavow caste and perform global modernity is stronger. However, the contradiction between giving to bright and deserving beneficiaries who share the same caste location as the donor, and the perception that declaring caste affiliation is backward, is somewhat resolved when meritocracy is upheld. It allows for the surreptitious workings of caste while delegitimizing its expression. 